Original Research Article

\title{
A comparative study on self medication practices in ACSR Government medical college in Nellore, India
}

\author{
Sree Nagamani Penupothu, Lalitha Hanumanthu*
}

\begin{abstract}
Department of Pharmacology, Dr. NTRUHS, Nellore, Andhra Pradesh, India
\end{abstract}

Received: 05 March 2018

Accepted: 03 April 2018

\section{*Correspondence to:}

Dr. Lalitha Hanumanthu, Email: drlalithah@gmail.com

Copyright: (C) the author(s), publisher and licensee Medip Academy. This is an openaccess article distributed under the terms of the Creative Commons Attribution NonCommercial License, which permits unrestricted noncommercial use, distribution, and reproduction in any medium, provided the original work is properly cited.

\begin{abstract}
Background: Self medication is rampant in medical undergraduates. There is a need to evaluate the extent and factors that govern self medication. This study was conducted in $7^{\text {th }}$ semester and 5 th semester undergraduates to compare the knowledge, attitude and practice regarding self medication.

Methods: It is a questionnaire based study in a total of 294 medical students comprising 147 students each belonging to 7th and 5th semesters to assess determinants and practice methods of self medication in the past one year.

Results: $100 \%$ of 7 th semester and $90 \%$ of 5 th semester students self medicated. Majority followed modern medicine. Awareness of OTC drugs, essential drugs and generic drugs was not optimum. Students self medicated based on old prescriptions and text books for perceived mild illnesses like common cold, fever and headache. Non steroidal anti-inflammatory drugs and antihistamines were most commonly used. Not all students checked package insert prior to use.

Conclusions: Self medication practice is more pronounced in 7 th semester than in 5th semester students. 7 th semester students used diverse drugs compared to 5 th semester students who used limited groups of drugs.
\end{abstract}

Keywords: Medical undergraduates, Over the counter drugs, Pharmacology, Self medication, Semester

\section{INTRODUCTION}

Self-care involves making responsible use of all medicines (prescription and non-prescription), self recognition of symptoms, self-monitoring and self-management. ${ }^{1}$ Selfmedication is one element of self-care. ${ }^{2}$ The use of medications without prior medical consultation regarding indication, dosage, and duration of treatment is referred to as self-medication. ${ }^{3}$ Self medication involves the use of medicinal products by the consumer to treat self recognized disorders or symptoms, or the intermittent or continued use of a medication prescribed by a physician for chronic or recurring diseases or symptoms. ${ }^{4}$ It will usually be selected for use in symptoms and conditions which the user regards as sufficiently troublesome to need medicinal treatment but not to justify consulting a physician. ${ }^{4}$ Medicines for self-medication are often called 'nonprescription' or 'over the counter' (OTC) and are available without a doctor's prescription through pharmacies. $^{5}$

There are pros and cons to practice of self medication. In less developed countries, self-medication is considered "responsible" because it may help to treat diseases that do not require medical attention and may reduce overuse of medical services; self medication's purpose is to solve minor health issues. ${ }^{6}$ The inappropriate use may result in irrational medicine use, delay in seeking medical advice, increased side effects and drug interactions. ${ }^{7}$

Self medication by undergraduates is usually the first step towards practical application of compiled knowledge from 
clinical postings and academic sessions. A study conducted at All India Institute of Medical Sciences, New Delhi observed that self-medication was considerably high among undergraduate medical and paramedical students in India and it increased with medical knowledge. ${ }^{8}$ There is a paucity of studies on self medication among medical students. ${ }^{9}$ This study was undertaken to gain insight into the outlook and practice methods of self medication in two successive batches of undergraduates. Our college first batch students are currently in $7^{\text {th }}$ semester and we compared their perception regarding self medication to the next batch i.e. $5^{\text {th }}$ semester students. Today's medical undergraduates are tomorrow's physicians. We intend to plan future sessions which inculcate responsible self medication practices on the basis of the observed results.

\section{METHODS}

An observational, cross-sectional, descriptive study was planned to compare the attitude and practice of self medication among undergraduate medical students in ACSR Government Medical College, Nellore. Two batches of the medical students were selected for the study. $1477^{\text {th }}$ semester students who cleared Pharmacology as part of II M.B.B.S Examination conducted by Dr. NTRUHS the previous year and $1475^{\text {th }}$ semester students who had not yet appeared for Pharmacology University Examination were selected to assess their self medication practices under their influence of studying Pharmacology. Total students from both the batches were 294. This study was done during a period of four months from 2017 November to 2018 February. After approval from Institutional Ethical Committee, ACSR GMC, Nellore, written Informed consent was obtained from the study participants. All the students participated with their own interest. A pretested semi-structured questionnaire was framed after referring the available literature. The questionnaire consisted of questions regarding the system of medicine followed, awareness of OTC drugs, Essential medicines and generic drugs, place of purchase of drugs, indications for medication, reasons for use, sources of drug information, package instructions, and drugs used during examination. This questionnaire was distributed to assess their practices and attitudes on self medication. They were given sufficient time to fill the questionnaire. The filled questionnaires were collected from the students. Data was entered in Microsoft Excel and analyzed using SPSS Software version 18. Results were displayed in terms of percentages, mean, tables and figures. Significance and association between two variables were assessed by using chi-square test.

\section{RESULTS}

In this study mean age of $7^{\text {th }}$ semester students are $21.3 \mathrm{yrs}$ while that of $5^{\text {th }}$ semester students is 20.4 years. $61 \%$ of $7^{\text {th }}$ semester students are females whereas in $5^{\text {th }}$ semester female students are $55 \%$ as shown in Table 1 . All the $7^{\text {th }}$ semester students $(100 \%)$ self medicated while approximately $90 \%(132)$ of $5^{\text {th }}$ semester students had self medicated as seen in Figure 1.

Table 1: Gender of the study participants.

\begin{tabular}{|lll|}
\hline Gender & $\begin{array}{l}\mathbf{7 t h} \text { semester } \\
(\mathbf{N}=147)\end{array}$ & $\begin{array}{l}\text { 5th semester } \\
(\mathbf{N}=147)\end{array}$ \\
\hline Male & 57 & 66 \\
\hline Female & 90 & 81 \\
\hline
\end{tabular}

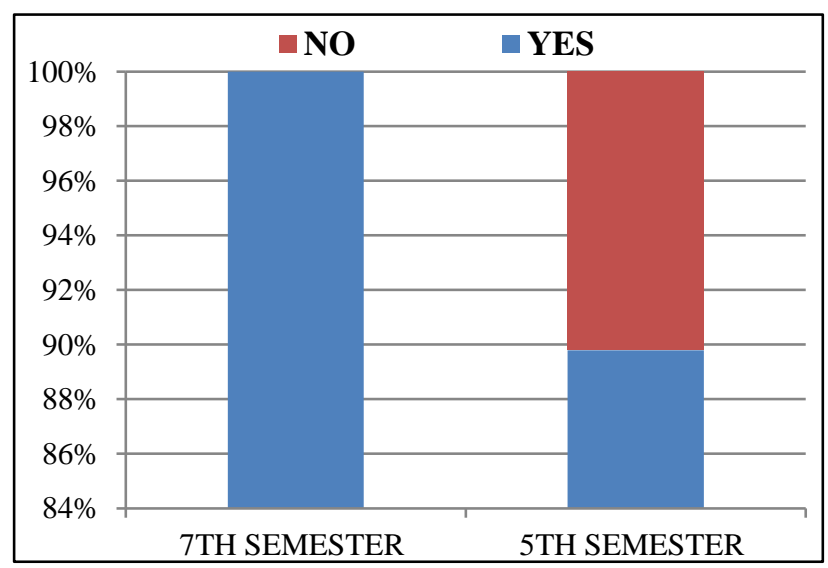

Figure 1: The prevalence of self medication in $7^{\text {th }}$ and $5^{\text {th }}$ semesters.

Majority of the $7^{\text {th }}$ and $5^{\text {th }}$ semester undergraduates follow modern medicine exclusively while around $10 \%$ of $5^{\text {th }}$ semester undergraduates follow homeopathy and Ayurveda system of medicine additionally as depicted in Figure 2.

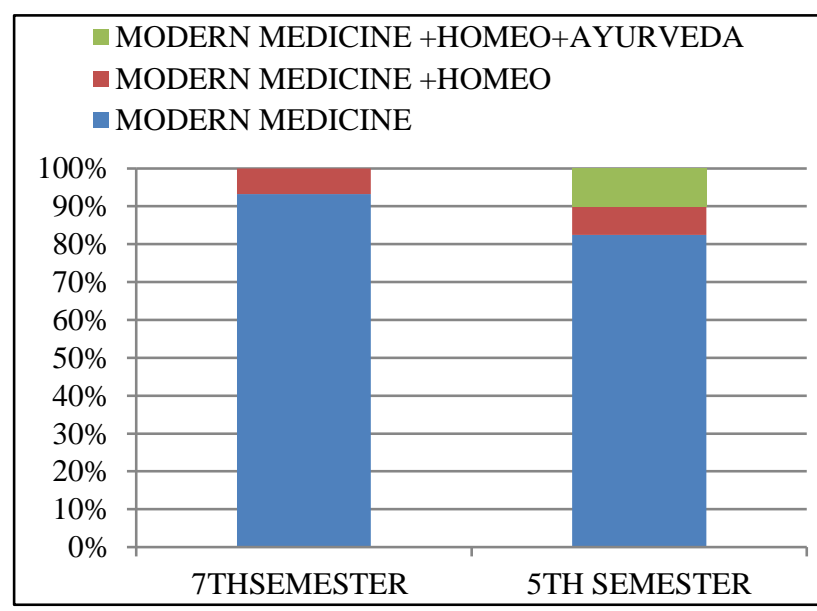

Figure 2: System of medicine followed by both semesters.

Surprisingly, awareness of the term 'over the counter drugs' (OTC drugs) was greater among $5^{\text {th }}$ semester students $(63 \%)$ compared to $7^{\text {th }}$ semester students $(55 \%)$ as shown in Figure 3. Although lower percentage of $5^{\text {th }}$ semester students are aware of generic drugs, greater proportion (one third) purchase from generic drug stores as seen in Figure 4. 


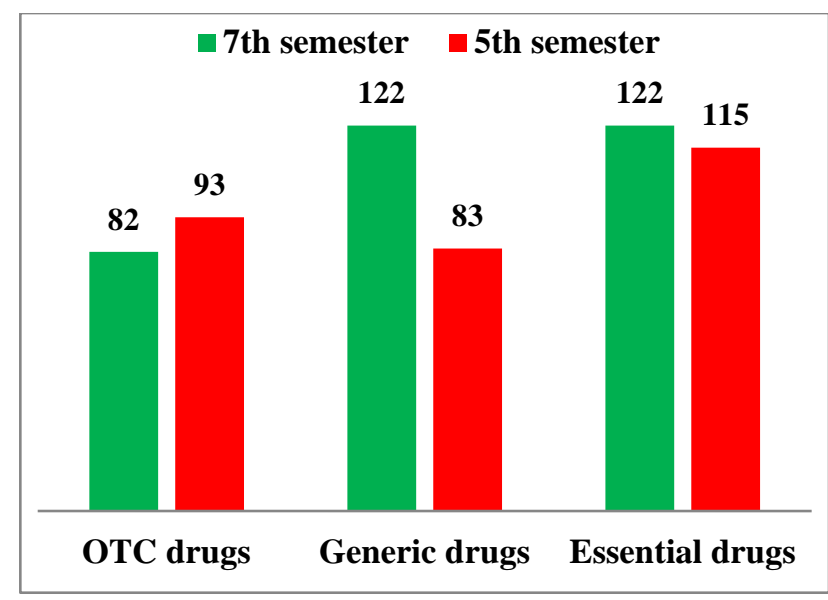

$\mathrm{P}<0.001$ statistically significant

Figure 3: Awareness of OTC (over the counter drugs), Generic drugs and Essential drugs in students.

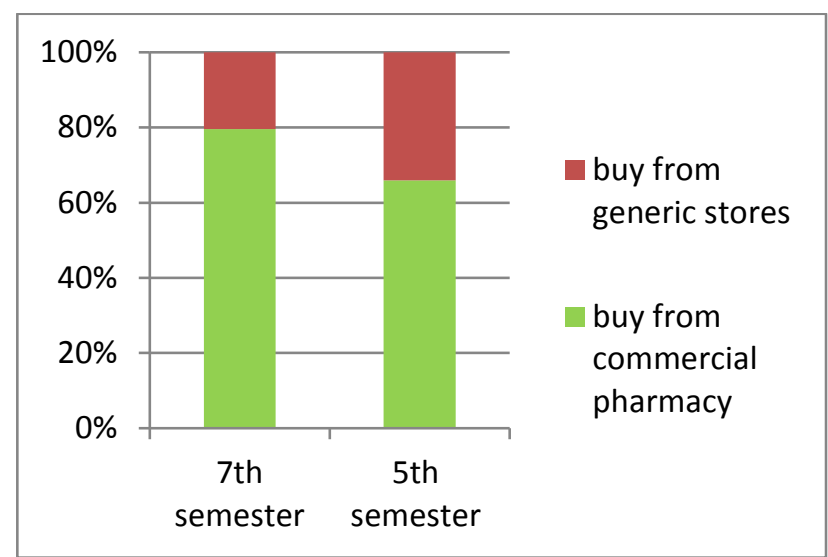

$\mathrm{P}<0.001$ statistically significant

Figure 4: Place of purchase of drugs by $7^{\text {th }}$ and $5^{\text {th }}$ semester students.

Table 2: Indications for self medication.

\begin{tabular}{|ll|l|}
\hline Indications & $\begin{array}{l}\boldsymbol{7}^{\text {th }} \text { semester } \\
(\mathbf{N}=\mathbf{1 4 7})\end{array}$ & $\begin{array}{l}\mathbf{5}^{\text {th }} \text { Semester } \\
(\mathbf{N}=\mathbf{1 3 2})\end{array}$ \\
\hline Common cold & 112 & 127 \\
\hline Fever & 100 & 107 \\
\hline Headache & 73 & 102 \\
\hline Cough & 49 & 88 \\
\hline APD & 20 & 14 \\
\hline Sore throat & 52 & 53 \\
\hline Vomiting & 31 & 25 \\
\hline Constipation & 18 & 12 \\
\hline Diarrhoea & 51 & 30 \\
\hline Mouth ulcer & 26 & 15 \\
\hline Allergy & 12 & 11 \\
\hline Wounds & 8 & 9 \\
\hline Dysmenorrhea & 54 & 40 \\
\hline Acne & 15 & 8 \\
\hline Psychotropics & 3 & 1 \\
\hline
\end{tabular}

$\mathrm{P}=0.92$ (not significant)
The most common indications where self medication was practised in decreasing order was common cold, fever, headache and cough as seen in Table 2. Use of drugs for dysmenorrhoea, diarrhoea, and acne was greater in $7^{\text {th }}$ semester students as depicted in Table 2.

In this study, the most common class of drugs used in selfmedication was analgesics followed by anti-histamines and antimicrobials as seen in Table 3. Greater use of Multivitamins, antispasmodics and antimicrobials was observed in $7^{\text {th }}$ semester students as depicted in Table 3 .

Table 3: Pharmacological classes of drugs used in self medication.

\begin{tabular}{|lll|}
\hline Class of drugs used & $\begin{array}{l}\mathbf{7}^{\text {th }} \text { semester } \\
(\mathbf{N}=\mathbf{1 4 7})\end{array}$ & $\begin{array}{l}\mathbf{5}^{\text {th }} \text { Semester } \\
(\mathbf{N}=132)\end{array}$ \\
\hline Nasal decongestants & 12 & 4 \\
\hline Anti histamines & 100 & 113 \\
\hline Analgesics & 139 & 128 \\
\hline Antipyretics & 39 & 14 \\
\hline Anti diarrhoeals & 51 & 30 \\
\hline Anti-emetics & 31 & 25 \\
\hline Laxatives & 18 & 12 \\
\hline Anti spasmodics & 54 & 40 \\
\hline Multivitamins & 45 & 33 \\
\hline Riboflavin & 15 & 2 \\
\hline Retinoids & 5 & 1 \\
\hline Benzoyl peroxide & 9 & 7 \\
\hline Antimicrobials & 112 & 67 \\
\hline $\begin{array}{l}\text { P }=0.46 \text { (not significant) } \\
\text { More than one option can be selected }\end{array}$ \\
\hline
\end{tabular}

Students of both batches used old prescription, text-book and took advice from family and friends as relied source of drug information while using self medication as seen in Figure 5.

Most common reason in favour of self medication in this study was found to be mild nature of illness and urgency as seen in Figure 6.

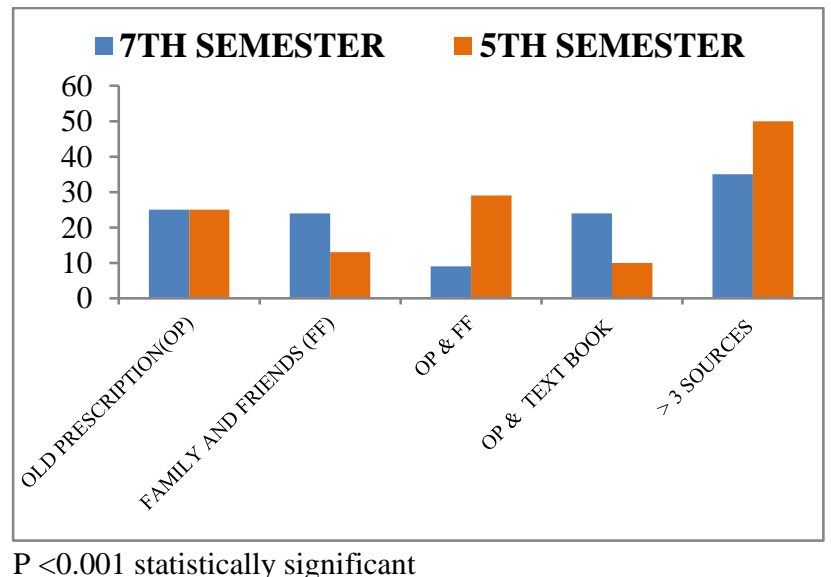

Figure 5: Sources of drug information for self medication. 


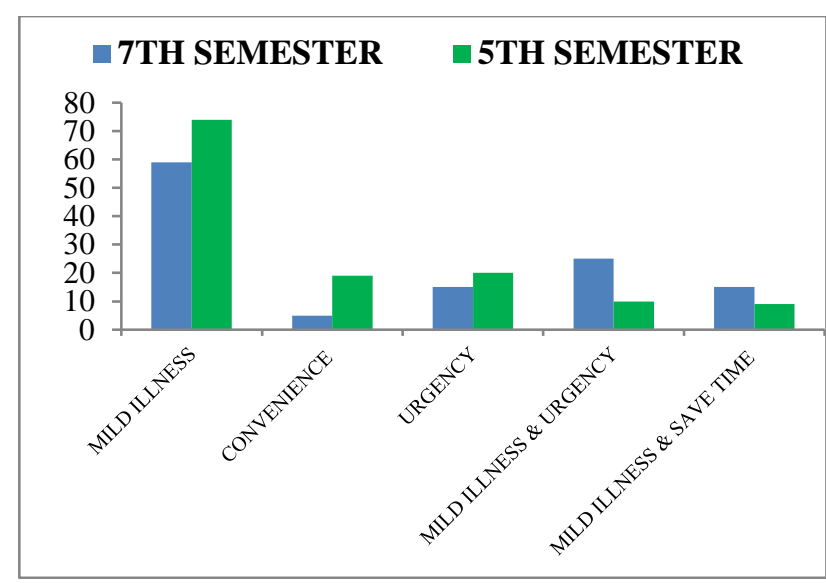

$\mathrm{P}<0.001$ statistically significant

Figure 6: Reasons for self medication.

Possibility of adverse drug reaction was the most common deterrent against practice of self medication as seen in Figure 7.

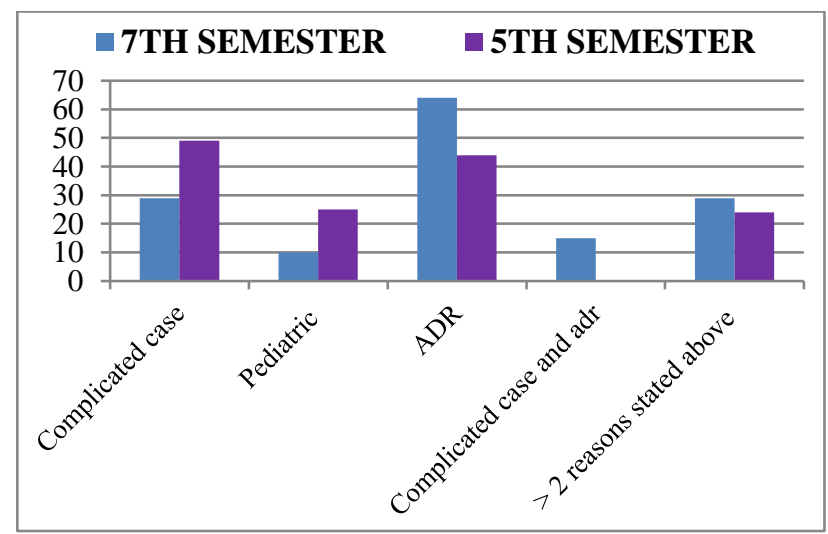

$\mathrm{P}<0.001$ statistically significant

Figure 7: Indications where self medication is not practised.

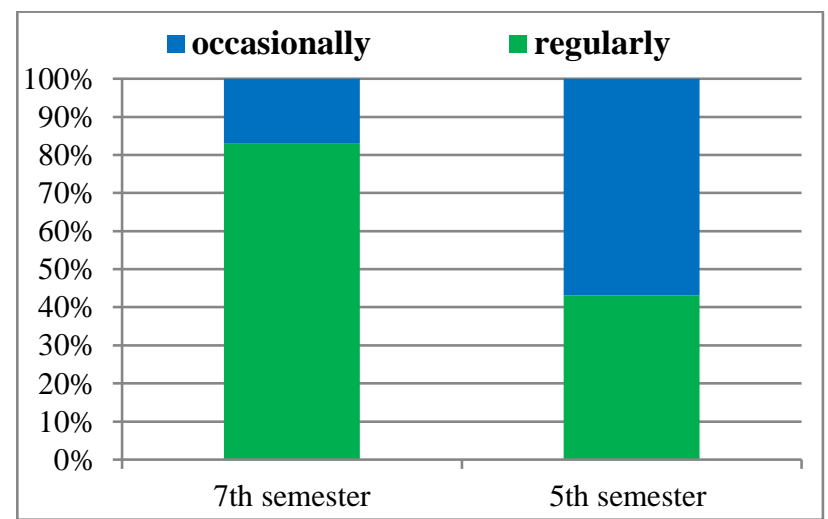

$\mathrm{P}<0.001$ statistically significant

Figure 8: Percentage of students who check package inserts regularly and occasionally.

In this study around $80 \%$ of $7^{\text {th }}$ semester students checked the package inserts regularly while only around $40 \%$ of $5^{\text {th }}$ semester students do so as seen in Figure 8.
Figure 9 shows usage of multivitamin preparations during stressful examination time was more prevalent among the $7^{\text {th }}$ semester students than the $5^{\text {th }}$ semester students. $3 \%$ of $7^{\text {th }}$ semester students also admitted to taking anxiolytics during exams.

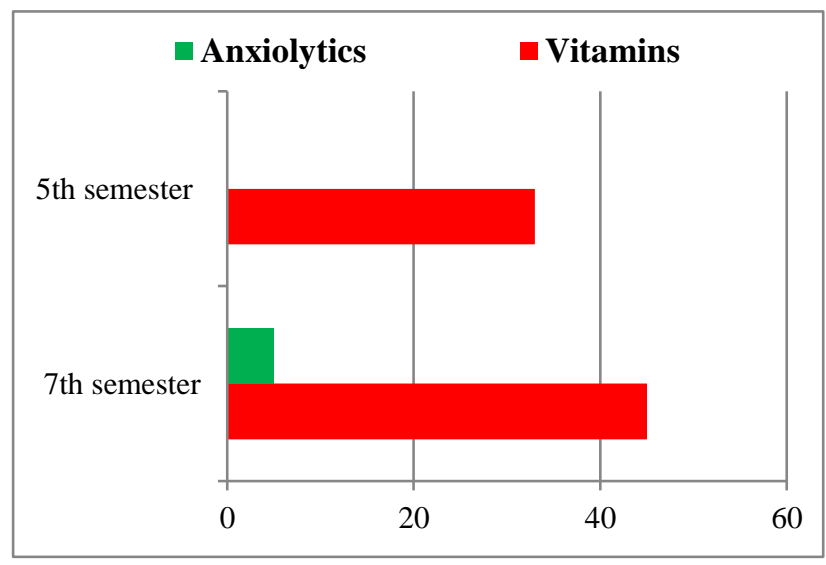

Figure 9: Usage of vitamins and anxiolytics during exams.

In this study, Paracetamol and Diclofenac were found to be the most commonly used analgesics in both semester students as seen in Fig10. $7^{\text {th }}$ semester students preferred to take Paracetamol $(28 \%)$ while $5^{\text {th }}$ semester students were in favour of Diclofenac (31\%) as seen in Figure 10.

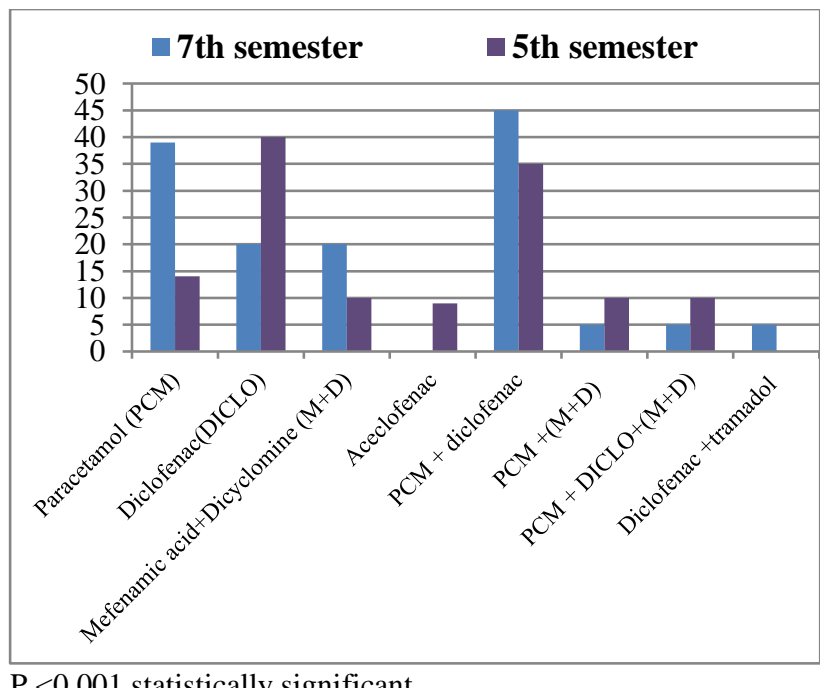

$\mathrm{P}<0.001$ statistically significant

Figure 10: Pattern of use of analgesics in $7^{\text {th }}$ and $5^{\text {th }}$ semester students.

As seen in Figure 11, the most commonly used antimicrobial agent in both batches was combination of amoxicillin with clavulanic acid followed by others like azithromycin, fluoroquinolones, metronidazole etc.

\section{DISCUSSION}

Previously, it was considered as unnecessary; however, responsible self-medication is regarded as an important 
aspect of self-care nowadays. ${ }^{10}$ Prevalence of self medication was higher among $7^{\text {th }}$ semester students $(100 \%)$ than $5^{\text {th }}$ semester students. This is similar to findings reported by Sawhney $\mathrm{V}$ et al where the prevalence of self-medication was $100 \%(n=122) .{ }^{11}$

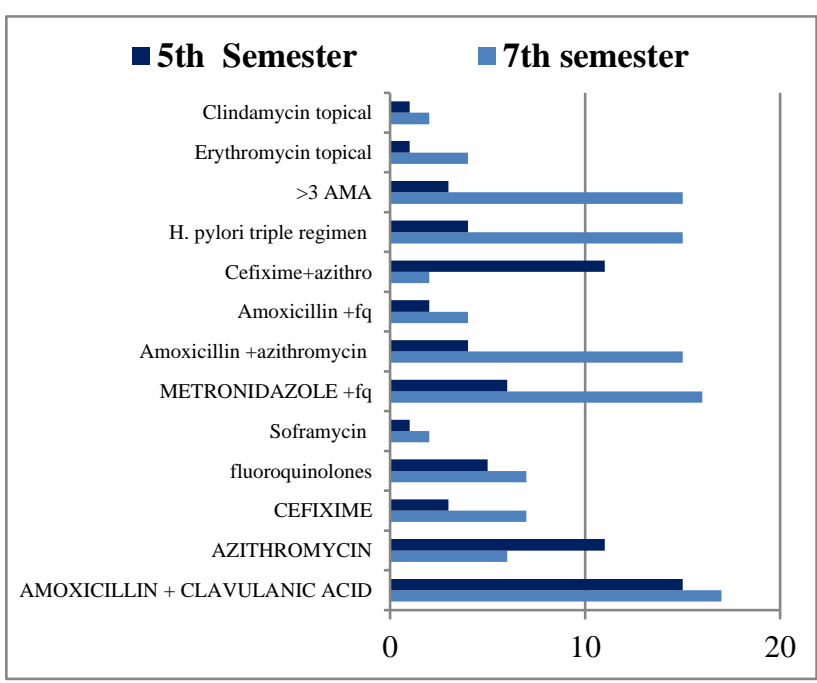

Figure 11: Pattern of antimicrobials used by $7^{\text {th }}$ and $5^{\text {th }}$ semester students.

In this study, the most common ailments where self medication was practised in both batches were common cold and fever. The pharmacological class of drugs commonly used in self-medication was analgesics for fever and headache followed by anti-histamines and antimicrobials. The most commonly used analgesics in both semester students were Paracetamol and Diclofenac. According to Sawhney et al, the most common symptoms leading to self-medication were headache (77.8\%), flu/cold and sore throat $(58.1 \%)$, and fever $(52.4 \%)$ and the drugs most commonly used were analgesics (74.5\%), headache relievers (71.3\%), antibiotics (64\%), and antipyretics (50.8\%). ${ }^{11}$ According to Sontakke et al, drugs most commonly used by self-medication were analgesics and antipyretics. ${ }^{6}$ According to Albasheer et al, among those who reported self-medication, $69 \%$ used it for pain management, $45 \%$ for cold symptoms. ${ }^{12}$ According to Zhu et al, flu-like symptoms as the major complaints for SMA (self medication for antibiotics). ${ }^{13}$

Students of both batches used mainly old prescription and text-books as source of drug information while using self medication. Most common reason in favour of self medication in this study was found to be mild nature of illness. These findings are similar to Fatimah Ali Albusalih et al study. ${ }^{14}$

Amoxicillin with clavulanic acid was the most commonly used antimicrobial by both batches in this study. According to Nithin kumar et al, Beta-lactams were most commonly used for self-medication, and sore throat was the most common indication for antibiotic use. ${ }^{15}$
According to Biplab pal et al, the most common antibiotic used by the medical students was amoxicillin $(74.6 \%) .{ }^{16}$

In the case of non-prescription medicinal products, all of the information required to permit safe and effective use must come from the labelling material, patient information texts, the individual's previous experience, and various sources of information in the media, advertising, and advice given by health care professionals. ${ }^{4}$ Leaflets included with OTC medicines also can be important information source, although the readability of some is poor. ${ }^{17}$ In this study, higher number of $7^{\text {th }}$ semester students checked the package inserts regularly when compared to $5^{\text {th }}$ semester students.

There is need to develop practical exercises to increase awareness of proper use of over the counter drugs (OTC) and Essential medicines. Students should be demonstrated that drugs purchased from generic stores are as equally effective as the branded drugs purchased from commercial pharmacy. They should be encouraged to check package inserts prior to drug use to promote judicious use in self medication.

Limitations of the study was students disclosed information related to events regarding self medication in the past year in response to the questionnaire. So, there is an inherent probability of recall bias.

\section{ACKNOWLEDGEMENTS}

Authors would like to thank their Professor and Head of Department of Pharmacology, Dr. V.L.M. Raman and Dr. Y. Lakshmi Associate Professor for their valuable guidance. Autors also thank Dr. Sowmya Sudha, Assistant Professor, Department of Community Medicine for her valuable input and Dr. G. Naveen choudary, Assistant Professor, Department of Pharmacology for his cooperation. Authors appreciate their students for their enthusiastic participation in this study.

Funding: No funding sources

Conflict of interest: None declared

Ethical approval: The study was approved by the Institutional Ethics Committee of ACSR GMC, Nellore, India

\section{REFERENCES}

1. World Self Medication Industry. What is Self Care? Available at: http://www.wsmi.org/about-self-careand-self-medication/what-is-self-care/

2. World Health Organization (WHO) Regional Office for South-East Asia. Self-care in the Context of Primary Health Care: Report of the Regional Consultation Bangkok, Thailand, 7-9 January 2009. Available at: http://apps.who.int/iris/bitstream/10665/206352/1/B4 301.pdf 
3. A World Health Organization resource: Essential Medicines and Health Products Information Portal. Available

at: http://apps.who.int/medicinedocs/en/d/Js22205en/

4. WHO. Guidelines for the Regulatory Assessment of Medicinal Products for Use in Self-Medication, Geneva; 2000. Available at: http://apps.who.int/medicinedocs/pdf/s2218e/s2218e. pdf

5. Sontakke SD, Bajait CS, Pimpalkhute SA, Jaiswal KM, Jaiswal SR. Sontakke SD, et al. Comparative study of evaluation of self-medication practices in first and third year medical students. Int J Biol Med Res. 2011;2(2):561-4.

6. Zaffani S, Cuzzolin L, Benoni G. Herbal products: behaviors and beliefs among Italian women. Pharmaco. Epidemiol. Drug Saf. 2006;15(5):354-9.

7. Sawalha AF. Assessment of Self-Medication Practice among University Students in Palestine: Therapeutic and Toxicity Implications. The Islamic University Journal (Series of Natural Studies and Engineering). 2007;15(2):67-82.

8. Self-medication popular among medical students: AIIMS study Available at: http://www.livemint.com/Politics/XcN44QD5g8aW4 dwltcUdtI/Selfmedicationpopular-among-medicalstudents-AIIMS-study.html

9. Henry J, Handu SS, Khalid AJ, Khaja ASO, Sequeira RP. Evaluation of the Knowledge, Attitude and Practice of Self-Medication among First-Year Medical Students. Med Princ Pract. 2006;15:270-5.

10. Garofalo L, Giuseppe GD, Angelillo IF. SelfMedication Practices among Parents in Italy. Bio Med. Res. Int. 2015.

11. Sawhney V, Bhat MY, Singh Z. A descriptive study of prevalence, pattern and attitude of self-medication among second professional medical students in a tertiary care center. International Journal of Basic \& Clinical Pharmacology. 2017 Jan 18;4(3):542-6.

12. Albasheer OB, Mahfouz MS, Masmali BM, Ageeli RA, Majrashi AM, Hakami AN, et al. Self-medication practice among undergraduate medical students of a Saudi tertiary institution. Tropical Journal of Pharmaceutical Research. 2016;15(10):2253-9.

13. Zhu X, Pan H, Yang Z, Cui B, Zhang D, Ba-Thein W. Self-medication practices with antibiotics among Chinese university students. Public health. 2016 Jan 1;130:78-83.

14. Albusalih FA, Naqvi AA, Ahmad R, Ahmad N. Prevalence of self-medication among students of pharmacy and medicine colleges of a public sector university in Dammam City, Saudi Arabia. Pharmacy. 2017 Sep 4;5(3):51.

15. Kumar N, Kanchan T, Unnikrishnan B, Rekha T, Mithra P, Kulkarni V, et al. Perceptions and practices of self-medication among medical students in coastal South India. PloS one. 2013 Aug 28;8(8):e72247.

16. Pal B, Murti K, Gupta AK, Choudhury U, Rastogi M, Pandey $\mathrm{H}$, et al. Self Medication with Antibiotics among Medical and Pharmacy Students in North India. American Medical Journal; 2016.

17. Nair MGS, Rajmohanan TP, Kumaran J. Self Medication Practices of Reproductive Age Group Women in Thiruvananthapuram District, South India: A Questionnaire - Based Study. J Pharm Sci \& Res. 2013;5(11):220-5.

Cite this article as: Penupothu SN, Hanumanthu L. A comparative study on self medication practices in ACSR Government medical college in Nellore, India. Int J Basic Clin Pharmacol 2018;7:941-6. 